\title{
Pengaruh Kepemimpinan Transformasional Kepala Sekolah Dan Motivasi Kerja Terhadap Kinerja Guru SMK Negeri Jakarta Utara
}

\author{
Sugiarto \\ Universitas Negeri Jakarta \\ sugiarto@unj.ac.id \\ Wahidin \\ Universitas Negeri Jakarta \\ wahidin_9910817017@mhs.unj.ac.id \\ Totok Amin Soefijanto \\ Universitas Negeri Jakarta \\ totok.soefijanto@gmail.com
}

\begin{abstract}
Teacher's performance plays a crucial role in achieving quality of education and good character of students. Low teacher's performance will decrease quality of graduates itself. Based on data in north Jakarta vocational school, teacher's performance is in priority programs of government, and still need to be increased. The objectives of this research is to investigate whether there exist any direct positive effect of transformational leadership and work motivation towards teacher's performance at North Jakarta Vocational School. As many as 81 from 443 teachers were used as research samples to obtain data which were then analyzed using quantitative methods of path analysis. The result shows that there exists a positive direct effect of (1) transformational leadership towards teacher performance, (2) work motivation towards teacher performance, (3) transformational leadership towards work motivation.
\end{abstract}

Keywords : Teacher's performance; Transformational leadership; Work motivation; Education.

Abstrak : Tujuan dari penelitian ini adalah untuk mengetahui apakah terdapat hubungan langsung positif kepemimpinan transformasional dan motivasi kerja terhadap kinerja guru SMK Negeri Jakarta Utara. Sebanyak 81 dari 443 guru digunakan sebagai sampel penelitian untuk memperoleh data yang kemudian dianalisis menggunakan metode kuantitatif analisis jalur. Hasil penelitian menunjukkan bahwa terdapat hubungan langsung positif (1) kepemimpinan transformasional terhadap kinerja guru, (2) motivasi terhadap kinerja guru, (3) kepemimpinan transformasional terhadap motivasi kerja.

Kata Kunci : Kinerja guru; Kepemimpinan transformasional; Motivasi kerja;

\section{Pendahuluan} pendidikan.

Peran guru sangat menentukan dalam usaha peningkatan mutu pendidikan. Guru sebagai agen perubahan dituntut mampu menyelenggarakan proses pembelajaran dengan sangat baik, dimana guru harus mempersiapkan kebutuhan siswa sesuai dengan kurikulum yang ada atau bahkan dapat dikembangkan dengan model pembelajaran yang relevan. Guru memiliki peran yang sangat strategis dalam bidang pendidikan, bahkan dikatakan guru sebagai sumber daya yang sangat diperlukan dalam dunia pendidikan, dimana guru dituntut untuk profesional dalam mengemban tanggungjawabnya dalam mendidik. Dengan kata lain, guru merupakan ujung tombak dalam upaya 
peningkatan kualitas layanan dan output pendidikan. Dewasa ini permasalahan sistem pendidikan muncul dengan berbagai kasus terkait dengan kualitas guru.

Peningkatan kualitas guru dalam mengajar harus disertai dengan peningkatan mutu guru. Sedangkan kenyataan dilapangan masih banyak kualitas guru yang berada pada tingkat kualifikasi standar minimal. Menurut Badan Program Pembangunan di bawah PBB (United Nations Development Programme/UNDP), Indeks Pembangunan Manusia (IPM) memberikan ukuran yang menjelaskan bagaimana penduduk dapat mengetahui hasil pembangunan dalam memperoleh pendapatan, kesehatan dan pendidikan. Dalam empat tahun terakhir, IPM Indonesia terus meningkat. Badan Pusat Statistik (BPS) mencatat peningkatan IPM dari 68,9 di tahun 2014, menjadi 70,81 di tahun 2017, angkat tersebut masuk dalam kategori "tinggi". Namun dalam peringkat global, angka tersebut jauh tertinggal dengan 189 negara, sehingga Indonesia hanya dapat menempati urutan ke 116.

Hal tersebut menunjukkan bahwa sumber daya manusia yang ada di Indonesia dari waktu ke waktu mengalami pengingkatan yang signifikan, rendahnya kualitas sumber daya manusia tersebut tidak lepas dari kualitas pendidikan di Indonesia. Berdasarkan Uji Kompetensi Guru dengan strandar kompetensi minimal yang ditetapkan yaitu 55,0 secara nasional, rata-rata uji kompetensi guru hanya mencapai nilai 53,02 yang dihasilkan setelah dilakukan uji kompetensi. Sedangkan berdasarkan dari hasil UKG hanya ada tujuh provinsi dengan nilai hasil UKG di atas standar, yaitu Jawa Barat $(55,06)$, Kepulauan Bangka Belitung (55,13), Bali (56,13), Jawa Timur (56,73), DKI Jakarta $(58,44)$, Jawa Tengah $(59,10)$ dan DI Yogyakarta $(62,58)$. Selain tujuh provinsi ditas yang mendapatkan nilai sesuai dengan standar kompetensi minimum, ada tiga provinsi yang mendapatkan nilai diatas rata- rata nasional yaitu kepulauan riua $(54,72$, Sumatera Barat $(54,68)$ dan Kalimantan Selatan $(53,16)$. Jikah dilihat dari hasil Uji Kompetensi Guru untuk kompetensi bidang pedagogik, rata-rata nasional hanya mampu mendapatkan hasil 48,94, yakni dibawah standar kompetensi minimal yaitu 55,00. Secara rinci nilai rata-rata untuk TK 58,87, SD 36,86, SMP 46.15, SMA 51,35, SMK 50,02.

Berdasarkan data tersebut menunjukkan bahwa masih perlu peningkatan kualitas guru yang sangat signifikan untuk mencapai standar minimal yang ditentukan secara nasional yaitu 55,00. Untuk mendukung penelitian ini, maka penulis mengangkat definisi konseptual dan penelitian terdahulu yang relevan sebagaimana dijabarkan dibawah ini.

\section{Kepemimpinan Transformasional}

Menurut Robbins dan Judge (2018:226) “Transformational leadership who inspire followers to transcend their self-interests for the good of the organization. Transformational leaders can have an extraordinary effect on their followers, who respond with increased levels of commitment, inti dari teori ini 
adalah kepemimpinan transformasional dapat menginspirasi para pengikut untuk melampui kepetingan diri pribadi mereka demi kebaikan suatu organisasi dalam artian seorang pemimpin harus dapat memberikan efek yang luar biasa kepada bawahannya dan dapat merespon dengan cepat apa yang dibutuhkan oleh bawahannya dengan tingkat komitmen yang tinggi. Shane dan Glinow (2010: 342) mendefinisikan kepemimpinan transformasional saat ini adalah perspektif kepemimpinan yang paling populer untuk menghadapi sejumlah tantangan. Atau didefinisikan sebagai seperangkat perilaku yang digunakan orang untuk memipin orang lain melalui proses perubahan. Yulk (2014:278) mengatakan perilaku pemimpin Transformasional adalah (1) mempengaruhi idealisme, (2) memperhatikan setiap individu,(3) memotivasi dengan memberi inspirasi, dan (4) mendorong potensi intelektual. Selanjutnya Bateman dan Snell (2018: 359) mengatakan "transformational leaders motivates people to transcend their personal interests for the sake of the large community. Pemimpin transformasional dapat memotivasi orang lain untuk melampaui kepentingan pribadi mereka demi komunitas besar. Setidaknya ada empat strategi tambahan yang dapat berkontribusi pada kepemimpinan transformasional yaitu: (a) pemimpin transformasional memiliki visi, tujuan, agenda atau orientasi hasil yang menarik perhatian orang, (b) pemimpin dapat mengomunikasikan visi mereka, melalui kata- kata, cara atau simbolisme, dapat menyampaikan gambar yang meyakinkan tentang tujuan akhir, (c) pemimpin transformasional membangun kepercayaan dengan konsisten, dapat diandalkan dan gigih, (d) Pemimpin memiliki harga diri yang positif.

Berdasarkan uraian konseptual di atas, maka dapat disintesiskan bahwa kepemimpinan transformasional adalah tindakan pemimpin dalam memperngaruhi bawahannya sehingga memiliki kemauan untuk bekerja dalam upaya pencapaian tujuan organisasi yang terdiri dari tiga komponen yaitu karisma, pertimbangan individual, dan stimulasi intelektual.

\section{Motivasi Kerja}

Mullins (2010: 253) mengatakan bahwa motivasi pada dasarnya berkaitan dengan mengapa orang berperilaku dengan cara tertentu. Pertanyaan mendasar yang mendasarinya adalah "Mengapa orang melakukan apa yang mereka lakukan? Secara umum, motivasi dapat digambarkan sebagai arah dan kegigihan tindakan. Lunenburg dan Omstein (2012: 80) menyatakan bahwa tanpa adanya motivasi kerja, seseorang pekerja termasuk guru, tidak akan bekerja dengan baik sehingga hasil pekerjaannya tidak akan memuaskan. Selanjutnya Santrock (2017: 510) mendefinisikan motivasi adalah proses yang memberi semangat, arah, dan kegigihan perilaku. Artinya perilaku yang dapat termotivasi adalah perilaku yang memiliki energi, sesuai dengan arahan, dan bertahan lebih lama. Sedangkan Lussiers dan Achua (2015: 79) menyatakan motivasi adalah segala sesuatu yang mempengaruhi perilaku dalam mengejar hasil tertentu. Robbins dan Coulters 
(2018: 520) mengatakan "The Process by which a person efforts are energized, directed, and sustained toward attaining a goal. Menurutnya motivasi adalah proses dimana upaya seseorang digerakkan, diarahkan dan dipertahankan untuk mencapai tujuan.

Berdasarkan deskripsi konseptual diatas, maka dapat disintesiskan bahwa motivasi kerja adalah suatu proses yang memperhitungkan intensitas, arah dan kegigihan upaya individu untuk mengarahkan segala upaya tingkat tinggi dengan memberikan dorongan dan semangat kepada diri sendiri baik secara sadar maupun tidak sara untuk mencapai tujuan organisasi.

\section{Kinerja Guru}

Secara konseptual, kinerja diartikan sebagai unjuk kerja seseorang atau sekelompok organisasi dengan penampilan yang menggambarkan dan menghasilkan sesuatu hal, baik yang bersifat fisik dan non fisik yang sesuai dengan petunjuk, fungsi, dan tugasnya masing-masing berdasarkan kemampuan dan keterampilan yang dimilikinya. Qolquit, Lepipne dan Wesson (2009: 33) memandang kinerja dinilai sebagai dari serangkaian perilaku karyawan yang berkontribusi, baik secara positif maupun negatif terhadap pencapaian tujuan organisasi. Campbell (1990) menyatakan bahwa kinerja merupakan perilaku karyawan yang terlibat sementara di tempat kerja yang berkontribusi untuk mencapai tujuan organisasi.

Konsep kinerja yang menekankan pada aspek perilaku juga dikemukakan oleh Viswesvaran (2011: 113), "job performance as evaluatable behaviors", menurut konsep ini, kinerja berarti perilaku-perilaku yang dapat dievaluasi. Sedangkan menurut Rothwell dan Kazanaz (2003: 402), dalam defini klasik, kinerja sebagai hasil dari pola tindakan yang dilakukan untuk memenuhi tujuan menurut beberapa standar. Perilaku kerja yang tepat dapat atau tidak dapat menghasilkan kinerja kerja yang baik.

Kinerja disamakan dengan hasil, perilaku disamakan dengan tindakan yang diambil untuk mencapai hasil. Definisi yang menekankan kinerja sebagai hasil juga dikemukakan oleh George dan Jones (2012: 158), kinerja adalah evaluasi dari hasil perilaku seseorang yang melibatkan, menentukan seberapa baik atau buru seseorang telah menyelesaikan suatu tugas atau melakukan pekerjaan. Sedangkan motivasi hanya satu faktor diantara banyak faktor yang berkontribusi terhadap kinerja pekerjaan karyawan. Viswevarn (2011: 114) kinerja berarti catatan keluaran yang dihasilkan pada fungsi atau aktivitas tertentu selama periode waktu yang telah ditentukan. Berdasarkan uraian di atas, maka peneliti melakukan penelitian dengan tema pengaruh kepemimpinan transformasional dan motivasi kerja terhadap kinerja guru SMK Negeri Jakarta Utara.

\section{Metode Penelitian}

Penelitian menggunakan pendekatan kuantitatif melalui analisis jalur atau path analisys dengan metode survey. Jenis penelitian ini lebih memfokuskan pada 
pengungkapan hubungan kausal antar variabel. Populasi dalam penelitian ini adalah guru SMK Negeri Jakarta Utara sebanyak 443 orang, dimana sampel ditentukan dari populasi dengan proposional random sampling secara acak berjumlah 81 orang. Dalam penelitian ini pengumpulan data yang digunakan dengan menggunakan instrumen berbentuk kuesioner. Instrumen diuji terlebih dahulu sebelum dipergunakan dalam penelitian. Pengujian instrumen tersebut meliputi keabsahan (validity) dan uji kehandalan (reliability).

Analisis data yang dgunakan untuk penelitian ini adalah analisis deskriptif dan analisis inferensial. Analisis deskriptif digunakan dalam hal penyajian data, ukuran sentral dan ukuran penyebaran. Analisis data dengan deskriptif dapat disajikan dalam bentuk tabel distribusi dan histogram. Analisis inferensial digunakan untuk menguji hipotesis yang memakai analisis jalur (path analysis) yang didahului dengan uji normalitas, galat taksiran dan analisis regresi berganda.

\section{Hasil Penelitian Dan Pembahasan}

Berdasarkan hasil perhitungan analisis jalur, adanya pengaruh langsung terhadap Kepemimpinan Transformasional dan Kinerja, nilai koefisien jalur sebesar 0,316 dan nilai t-hitung sebesar 5,42. Nilai t-tabel untuk $\alpha=0,05$ sebesar 1,99. Oleh karena nilai t-hitung lebih besar dari pada nilai t-tabel maka dengan demikian $\mathrm{H}_{\mathrm{o}}$ ditolak dan $\mathrm{H}_{1}$ diterima yaitu bahwa Kepemimpinan Transformasional berpengaruh secara langsung terhadap Kinerja dapat diterima. Hasil analisis hipotesis pertama memberikan temuan bahwa Kepemimpinan Transformasional berpengaruh secara langsung positif terhadap Kinerja. Dengan demikian dapat disimpulkan bahwa kinerja dipengaruhi secara langsung positif oleh Kepemimpinan Transformasional, sehingga meningkatnya Kepemimpinan Transformasional mengakibatkan peningkatan Kinerja.

Berdasarkan hasil perhitungan analisis jalur, pengaruh langsung Motivasi Kerja terhadap kinerja, nilai koefisien jalur sebesar 0,676 dan nilai t-hitung sebesar 11,21. Nilai t-tabel untuk $\alpha=0,05$ sebesar 1,99 . Oleh karena nilai t-hitung lebih besar dari pada nilai t-tabel maka $\mathrm{H}_{\circ}$ ditolak dan $\mathrm{H}_{1}$ diterima, dengan demikian Motivasi Kerja berpengaruh secara langsung terhadap kinerja dapat diterima. Hasil analisis hipotesis kedua menghasilkan temuan bahwa Motivasi Kerja berpengaruh secara langsung positif terhadap kinerja. Berdasarkan hasil temuan tersebut dapat disimpulkan bahwa Kinerja dipengaruhi secara langsung positif oleh Motivasi Kerja. Meningkatnya Motivasi Kerja mengakibatkan peningkatan Kinerja.

Berdasarkan hasil perhitungan analisis jalur, pengaruh langsung terhadap Motivasi Kerja, nilai koefiesien jalur sebesar 0,690 dan nilai t-hitung sebesar 2,21. Nilai t-tabel untuk $\alpha=0,05$ sebesar 1,99 . Oleh karena itu nilai t-hitung lebih besar dari pada nilai t-tabel makan dengan demikian $\mathrm{H}_{0}$ ditolak dan $\mathrm{H}_{1}$ diterima yaitu bahwa Kepemimpinan Transformasional berpengaruh secara langsung terhadap Motivasi Kerja dapat diterima. Hasil analisis hipotesis ketiga 
memberikan temuan bahwa Kepemimpinan Transformasional berpengaruh secara langsung positif terhadap Motivasi Kerja. Dengan demikian dapat disimpulkan bahwa Motivasi Kerja dipengaruhi secara langsung positif oleh Kepemimpinan Transformasional. Meningkatnya Kepemimpinan Transformasional mengakibatkan peningkatan Motivasi Kerja. Peran kepemimpinan tidak hanya tentang arah suatu organisasi yang kuat dimana permasalahan dan solusi banyak diketahui, tetapi peran kepemimpinan mengambil bagian dalam suatu konteks yang terjadi dalam perubahan secara berkesinambungan.

Berdasarkan hasil pengujian hipotesis pertama dapat disimpulkan bahwa terdapat pengaruh langsung positif Kepemimpinan Transformasional terhadap Kinerja dengan nilai koefisien korelasi sebesar 0,976 dan nilai koefisien jalur sebesar 0,856. Dari hasil pengujian hipotesis kedua dapat disimpulkan bahwa terdapat pengaruh langsung positif Motivasi Kerja terhadap Kinerja dengan nilai koefisien korelasi sebesar dan nilai koefisien jalur sebesar. ini memberikan makna Motivasi Kerja berpengaruh langsung terhadap Kinerja. Dari hasil pengujian hipotesis ketiga dapat disimpulkan bahwa terdapat pengaruh langsung positif Kepemimpinan Transformasional terhadap Motivasi Kerja dengan nilai koefisien korelasi sebesar dan nilai koefisien jalur sebesar 0,855.

Hasil penelitian ini telah memberikan arah bahwa Kepemimpinan Transformasional erat hubungannya dengan peningkatan motivasi kerja. Motivasi Kerja ditentukan oleh faktor kepemimpinan transformasional di sekolah.

Hasil pengujian hipotesis menunjukkan bahwa secara empiris: (1) Peningkatan kepemimpinan transformasional yang dilakukan oleh seorang pemimpin memberikan dampak terhadap kinerja. Dalam hal ini, kepala sekolah sebagai pemimpin di sekolah dapat memotivasi kinerja guru dalam kegiatan belajar di sekolah, kepala sekolah memberi contoh yang baik dalam hal kepemimpinan di sekolah, dan kepala sekolah bekerjasama dengan guru untuk meningkatkan kualitas pembelajaran dan kinerja para guru di sekolah; (2) Peningkatan motivasi kerja akan memberikan dampak terhadap kinerja.

\section{Kesimpulan}

Berdasarkan analisis dan pembahasan pengaruh kepemimpinan transformasional, motivasi kerja dan Kinerja guru SMK Negeri Jakarta Utara dapat disimpulkan sebagai berikut: (1) Kepemimpinan transformasional berpengaruh langsung positif terhadap kinerja guru. Artinya perubahan peningkatan kepemimpinan transformasional akan menyebabkan peningkatan pada kinerja guru SMK Negeri Jakarta Utara. (2) Motivasi Kerja berpengaruh langsung positif terhadap kinerja guru. Artinya perubahan peningkatan Motivasi Kerja akan menyebabkan peningkatan pada kinerja guru SMK Negeri Jakarta Utara. (3) Kepemimpinan Transformasional berpengaruh langsung 
terhadap motivasi kerja. Artinya perubahan peningkatan kepemimpinan transformasional yang akan menyebabkan peningkatan pada motivasi kerja guru SMK Negeri Jakarta Utara. Dengan demikian kepemimpinan transformasional dan motivasi kerja harus ditingkatkan dan diperbaiki sehingga kinerja guru dapat memberikan pengaruh dan kontribusi yang optimal pada perkembangan dan kemajuan pendidikan di Jakarta Utara. Langkah-langkah yang harus dilakukan dalam meningkatkan Kinerja Guru :

Pertama kepemimpinan transformasional kepala sekolah harus difokuskan pada komunikasi terbuka mengenai peraturan, program kerja yang disepakati bersama sehingga guru dapat merencanakan dan mempunyai target untuk mengembangkan diri secara kreatif dan inovatif, seperti menaikan jabatan fungsional dan meningkatkan keilmuan. Kepala sekolah juga meningkatkan motivasi kepada guru agar lebh baik lagi kinerjanya. Kedua, pengembangan keprofesionalisasi berkelanjutan (PKB), Ketiga, adanya analisis hasil Uji Kompetensi Guru yang dilakukan setiap tahun dan bukan lima tahun sekali agar kinerja guru lebih baik lagi. Keempat, Kepala sekolah melakukan Revitalisasi KKG/MGMP untuk meningkatkan kinerja guru.

\section{Daftar Pustaka}

Andang, 2014, Manajemen Kepemimpinan \& Kepemimpinan Kepala Sekolah: Konsep, strategi, \& inovasi menuju sekolah efektif. Jogjakarta: Ar-Ruzz Media

Bateman, Snell, 2019, Management: Leading \& Collaborating in a competitive world, Thirteenth edition, New York: McGraw-Hill education

Bethany and Carlos Tasso, 2019, Effective and Creative Leadership in diverse Worforces, Springer International

Bush, Tony, 2008, Leadership and Management Development in Education, London: SAGE Publication Ltd

Champoux, Joseph E, 2017, Organizational Behavior : Integrating individuals, Groups, and Organizational, New York : Routledge

Colquit, Jason A, Jeffrey A Lepipne dan Michael J.Wesson, 2009, Organizational Behavior, Improving Performance Commitment in The Workplace, (New York: McGraw Hill.

Duryat, Masduki, 2016, Kepemimpinan Pendidikan (Meneguhkan Legitimasi dalam Berkontestasi di Bidang Pendidikan). Bandung:: Alfabeta, 2016

Facette, Felicia Fersita, 2019, Minim Guru Kompeten, beban berat lulusan SMK penuhi Kebutuhan Industri. Artikel Tersedia Online. https://www.jawapos.com/nasional/23/02/2018/minim-guru-kompetenbeban-berat-lulusan-smk-penuhi-kebutuhan-industri/ (diakses pada, 18 Juli 
2019 pk.11.20 WIB

George, Jennifer M. dan Hareth R.Jones, 2012, Understanding and Managing Organizational, Fifth Ed. New Jersey: Pearson Education.

Ghaleb, Tareq,2016, The Impact of Transformational Leadership Style on Organizational Performance: Evidence form Jordan, Vol.6, No.2

Hartinah,http://jurnaldikbud.kemdikbud.go.id/index.php/jpnk/article/view/4 /2, diakses pada tanggal 24 juli 2019 pk. 11.20 WIB

Hutapea,Erwin,2019,https://edukasi.kompas.com/read/2019/07/22/14405261 /kepala-sekolah-harus-memiliki-5-kompetensi-ini?page=all, di akses pada tanggal 23 Juli 2019, pk. 14.41WIB

Ivancevich, John M, James L.Gibson, et.all, 2012, Organizations: Behavior, Structure, Processes, fourteenth Edition, New York: McGraw-Hill

Ivancevich, John M., Robert Konopaske, Michael T.Matteson, 2014, Organizational Behavior \& Management, America: McGraw-Hill

Jex, Steve M. and Thomas W.Britt, 2014, Organizational Psychology: A Scientist - Practionioner Approach, New Jersey: John Wileys \& Sons.

Jihad, Asep dan Suyanto, 2013, Menjadi Guru Profesional. Jakarta: Erlangga, Cet. Ke-17.

Jyoti, Jeevan, 2016, Transformational Leadership and Job Performance : A Study of Higher Education, Vol.15, No.2

Kartini, Sujanto Bedjo, Mukhneri,2017, The influence of organizational climate, transformational leadership, and work motivation on teacher job performance, vol.1, No.1

Kompri, 2015, Motivasi Pembelajaran: Perspektif Guru dan Siswa. Bandung: PT.Remaja Rosdakarya.

Lunenburg, Fred C. and Allan C Ornstein, 2012, Educational Administration: Concept and Practices, Sixth Edition, Canada: Nelson Education

Lussier, Robert N dan Christoper F.Achua, 2016, Leadership: Theory, Application, \& Skill Development, Canada: Cengage Learning.

Maulipaksi, Deliana, 2019, 242.308 Orang ikut uji kompetensi guru dan kepala sekolah.ArtikelTersediaOnline.https://www.kemdikbud.go.id/main/blog/ 2015/03/242308-orang-ikuti-uji-kompetensi-guru-dan-kepala-sekolahtahun-2015-3982-3982-3982, diakses pada tanggal 06 Agustus 2019 pk. $10.00 \mathrm{WIB}$ 
McShane, Steven L., Mary Ann Von Glinow, 2005, Organizational Behavior. Emerging Realities fot the Workplace Revolution, New York: McGrawHill Irwin

McShane, Steven, Von Glinow, 2018, Organizatonal Behavior: emerging knowledge, global reality, eighth edition, McGraw-Hill Education: New York

Mudawiya, Siti, Dewi Prihatini dan Deasy wulandari, 2019, The Role of Transformational Leadership, Motivation, Performane Allowance On Job Satisfaction and Empolyee Performance..., International Journal of Scientific \& Technology, Vol.8 Issue 01

Mullins, Laurie J, 2010, Management \& Organisatiinal Behavior, Ninth edition, London: Pearson Education Limited

Musriadi, 2016, Profesi Kependidikan Secara Teoritis dan Aplikatif: Panduan Praktis Bagi pendidik dan calon pendidik. Yogyakarta: Deepublish, Cet.1

Neck, Christopher P., Jeffery D.Houghton, dan Emma L Murray, 2017, Organizational Behavior: A Critical Thinking Approcah. America: Sage Publication

Norlander-Case. The profesional teacher: The Preparation and Nurturance Of The Reflective Pactitioner. Translated by Suci Romadhona, Jakarta: PT.Indeks, 2009

Panda, Didi, 2018, Kinerja Guru: Kompetensi, motivasi kerja, dan Kepemimpinan kepala sekolah, Sukabumi: Cv Jejak

Parkay, Forrest W dkk, 2011, Becoming a Teacher Eighth Edition. Translated by Wasi Darwanto, Jakarta: PT.Indeks

Priansa. Donni Juni, 2017, Menjadi Kepala Sekolah dan Guru Profesional: Konsep, Peran Strategis, dan Pengembangannya. Bandung: CV Pustaka Setia

Putra, Manggala Yudha, 2018, Kompetensi Guru Masih Kendala Utama SMK. ArtikelTersediaOnline.https://www.republika.co.id/berita/pendidikan/ed uaction/18/03/03/p4zo5r284-kompetensi-guru-masih-kendala-utama-smk (diakses pada tanggal 18 Juli 2019 pk. 8.23 WIB

Ramchunder, Yvete, 2012, The Role of Emotional and Self-Efficacy as Attributes of Leadership Effectiveness, South Africa

Rashmi, Surya, 2015, Impact of Transformational Leadership over Employee morale and Motivation, Indan Journal of Science and Technology,Vol.8 No.2 
Robbins, Stephen P dan Mary Coulter.2018, Management, (New York: Pearson Education.

Robbins, Stephen P dan Timothy A Judge, 2017, Organizational Behavior, seventeenth edition, London: Pearson Education Limited

Robbins, Sthephen P and Timothy Judge, 2018, "Essentials of Organizational Behavior", 14th edision, London : Pearson Education

Rothwell, William J dan H.C Kazans, 2003, The Stategic Development of Talent, A Completel Revised and Updated Second Edition of human Resource Development: A Strategic Approach, Amhert: HRD Press.

Santrock, John W, 2017, Educational Psychology, second edition. Translated by Tri wibobo. New York: McGraw Hill- Education

Setyo, P Thoni, Noermijati, Wirawan Dodi, 2017, The Influence of Transformational leadersip and work motivation on employee performance mediated by job satisfaction, Vo.1 No.2

Sobirin, 2018, Kepala Sekolah, Guru dan Pembelajaran, Bandung : Nuansa Cendekia.

Steven L dan Von Glinow, 2018, Organizational Behavior : Emerging knowledge, global reality, 8th edision, New York : McGraw-Hill Education

Sukarta, Mad Rodja dan Ahmad Sastra, 2011, Kepemimpinan Organisasi Pesantren. Bogor: Darul Muttaqien Press

Susanto, Ahmad, 2016, Manajemen Peningkatan Kinerja Guru: Konsep, Strategi, dan Implementasi. Jakarta: Kencana.

Tsui, Ming-sum, 2005,Social Work Supervision: Contexts and Conceps, California: Sage Publications.

Uno, Hamzah B dan Nina Lamatenggo, 2016, Tugas Guru Dalam Pembelajaran. Jakarta: Bumi Aksara.

Viswesvaran, Chockalingan, 2011, Assesment of Individual Job Performance: A Review of the Past Century and a Lokk Ahead, Handbook of Industrial, Work \& Organizational Psychology, Vol.1 (London: SAGE Publication).

Wicaksono, Ady Baskoro dan Sugeng Wahyudi, 2011, Pengaruh Efektivitas Kepemimpinan terhadap Kepuasan Kerja Pegawai, Jakarta.

Yamin, Maritinis, 2006, Sertifikasi Profesi Keguruan di Indonesia. Jakarta: Gaung Persada Press.

Yulk, Gary A, 2014, Leadership in Organization, New York: Pearson. 